\title{
SOCIAL DEMAND FOR THE FUTURE OF RUSSIA WITHIN POLITICAL PROJECTS AND MASS POLITICAL CONSCIOUSNESS
}

\author{
Aleksander A. Vilkov \\ Saratov State University named after N.G. Chernyshevsky, Saratov, Russian Federation \\ Nikolaj I. Shestov \\ Saratov State University named after N.G. Chernyshevsky, Saratov, Russian Federation
}

Andrei V. Abramov

Lomonosov Moscow State University, Moscow, Russian Federation

\begin{abstract}
Introduction. The purpose of this article is to find out to what extent the "social state" concept, brought to the fore of domestic political, social, and economic agendas by amendments to the Constitution of the Russian Federation, is able to satisfy the demand of the mass political consciousness in Russia for the image of the country's future. Methods and materials. To solve this problem, a wide range of general scholarly and specific political science approaches and methods were used. The conclusions are based on the results of opinion polls conducted by the largest social surveys research organizations of Russia (i.e. "Russian Public Opinion Research Center", "Levada-Center", and "Public Opinion Foundation"), analysis of the programs of political parties, speeches of Russian politicians, as well as on the observation over the Russian political process. Analysis. The views of citizens on the prospects for the development of relations between the state and society in Russia are analyzed in relation to the political projects of leading Russian political actors; the prospects of key projects of the existing political, social, and economic system optimization in the context of their compliance with the needs of various social groups in modern Russia are considered; estimation of social risks of their implementation is given. Results. An inference is made that formation of a socially desired image of the future of Russia requires a significant adjustment of the main Russian political actors' activities. Domestic political parties need a renewal of their leadership and relevant institutional and ideological reformatting; the highest bodies of state power need to adjust the political course - first of all, it is necessary to establish control over the use of natural resources, introduce a differentiated taxation system, and stimulate production. The lack of a clear response from government bodies and party structures to society's requests for a just, socially responsible state creates risks for the stability of the domestic social and political system, and can be used by destructive political forces to implement the scenario of a "colour revolution" in Russia.

$\vec{\sim} \quad$ Key words: public opinion, image of the future, political projects, social demand, mass political consciousness of Russians.

Citation. VilkovA.A., Shestov N.I., Abramov A.V. Social Demand for the Future of Russia Within Political Projects and Mass Political Consciousness. Vestnik Volgogradskogo gosudarstvennogo universiteta. Seriya 4. Istoriya. Regionovedenie. Mezhdunarodnye otnosheniya [Science Journal of Volgograd State University. History. Area Studies. International Relations], 2021, vol. 26, no. 3, pp. 108-122. (in Russian). DOI: https://doi.org/10.15688/jvolsu4.2021.3.10

\section{СОЦИАЛЬНЫЙ ЗАПРОС НА БУДУЩЕЕ РОССИИ В ПОЛИТИЧЕСКИХ ПРОЕКТАХ И МАССОВОМ СОЗНАНИИ ГРАЖДАН}

\section{Александр Алексеевич Вилков}

Саратовский национальный исследовательский государственный университет им. Н.Г. Чернышевского, г. Саратов, Российская Федерация 


\section{Николай Игоревич Шестов}

Саратовский национальный исследовательский государственный университет им. Н.Г. Чернышевского, г. Саратов, Российская Федерация

\section{Андрей Вячеславович Абрамов}

Московский государственный университет им. М.В. Ломоносова, г. Москва, Российская Федерация

Аннотация. Введение. Целью настоящей статьи является поиск ответа на вопрос о том, насколько сегодня концепт «социального государства», выведенный поправками к Конституции РФ на первый план внутрироссийской политической и социально-экономической повестки, способен удовлетворить запрос массового сознания российских граждан на образ будущего страны. Методы и материалы. Для решения указанной проблемы использован широкий набор общенаучных и специально-политологических подходов и методов (исторический, социологический, компаративный, аксиологический). Выводы базируются на результатах социологических опросов, проведенных крупнейшими социологическими службами России (ВЦИОМ, Левада-Центр, ФОМ), анализе программ политических партий, выступлений российских политических деятелей, а также на наблюдении за российским политическим процессом. Анализ. Проанализированы представления граждан о перспективах развития взаимоотношений между государством и обществом в России в их соотнесении с политическими проектами ведущих российских политических акторов; рассмотрены перспективы ведущих проектов оптимизации существующей политической и социально-экономической системы в контексте их соответствия запросам различных социальных групп в современной России, дана оценка социальным рискам их реализации. Результаты. Сделан вывод о том, что формирование социально востребованного образа будущего России требует существенной корректировки деятельности основных российских политических акторов. Отечественным политическим партиям необходимо обновление лидерского состава и соответствующее институциональное и идеологическое переформатирование; высшим органам государственной власти необходима корректировка политического курса: прежде всего шаги в направлении установления контроля над использованием природных ресурсов, внедрения дифференцированной системы налогообложения, мер по стимулированию производства. Отсутствие внятного ответа со стороны государственных органов и партийных структур на запросы общества о справедливом, социально ответственном государстве создает риски для устойчивости отечественной социально-политической системы, может использоваться деструктивными политическими силами для реализации сценария «цветной революции» в России. Вклад авторов. Разработка концепции статьи, написание вводного раздела, анализ программ политических партий и материалов социологических опросов, общее редактирование принадлежит А.А. Вилкову. Проведение теоретико-методологического анализа социального запроса на образ будущего России и его историческую обусловленность осуществил Н.И. Шестов. Сбор, систематизацию и анализ результатов социологических опросов, отражающих представления россиян о социально справедливом общественно-политическом устройстве страны реализовал А.В. Абрамов.

Ключевые слова: общественное мнение, образ будущего, политические проекты, социальный запрос, массовое политическое сознание россиян.

Цитирование. Вилков А. А., Шестов Н. И., Абрамов А. В. Социальный запрос на будущее России в политических проектах и массовом сознании граждан // Вестник Волгоградского государственного университета. Серия 4, История. Регионоведение. Международные отношения. - 2021. - Т. 26, № 3. - С. 108-122. DOI: https://doi.org/10.15688/jvolsu4.2021.3.10

Введение. Усиление внутриполитических конфликтов во многих странах современного мира, в том числе передовых по показателям политического и экономического благополучия, и обострение, особенно в последние годы, международных отношений в очередной раз актуализировали в повестке глобального и странового политических процессов проблему выбора обществами стратегий и моделей своего развития. Для российского общества и политической элиты актуальность такого выбора была устойчивой на протяжении всего постсоветского периода и в результате потерь в ресурсах функциональности, которые понесло государство от попыток его радикального реформирования, и в силу несостоявшихся надежд российских граждан на быструю и безболезненную интеграцию в культурное и экономическое пространство Запада. Недавние изменения в Конституции 


\section{ПОЛИТИЧЕСКИЙ ПРОЦЕСС В СОВРЕМЕННОЙ РОССИИ}

РФ, закрепившие ежегодную индексацию социальных выплат и пенсий, обязанность государства поддерживать доступность и качество медицинского обслуживания, гарантию социальной поддержки детей и другие изменения, представляют собой, по сути, усилие властной элиты сформулировать для российского общества новые ориентиры для политического взаимодействия с ней и для общего продвижения страны к социально-экономическому благополучию. Понятие «социальное государство» призвано образно обозначить общий позитивный тренд укрепления солидарности общества и власти в их представлениях о будущем России и продвижении к этому будущему. Однако важнейшее значение имеет вопрос: насколько это усилие в том виде и в том порядке, в котором оно было реализовано, соответствует социальным ожиданиям большинства российского населения?

Большинство граждан современных стран, и Россия здесь не исключение, воспринимает политическое бытие на уровне обыденного сознания. В массовом сознании постоянно идет творческая работа над образом будущего страны, государства, общества и человека, опирающаяся на житейский опыт отдельных людей и социальных групп. Результатом является обычно несистематический, фрагментарный политический образ будущего [23, с. 89-90]. Вместе с тем он обладает мощным мотивационным потенциалом, который может выступать эффективным мобилизационным ресурсом, стимулирующим и консолидирующим активность и социальную энергию общества. В то же время, если этот образ недостаточно коррелирует с идеологическими моделями и теоретическими проектами, выработанными властной и интеллектуальной элитами и внедряемыми в массовое сознание, он может стать дестабилизирующим и деструктивным фактором политического процесса.

Насколько сегодня концепт «социального государства», выведенный поправками к Конституции РФ на первый план внутрироссийской политической и социально-экономической повестки, способен удовлетворить запрос массового сознания российских граждан на образ будущего страны? Такой образ, который был бы способен в обозримой перспек- тиве поддерживать демократическую устойчивость политического процесса в нашей стране, достигнутую немалыми усилиями власти и общества в последние годы. И крайне уязвимую, как показывает опыт сопредельных с Россией стран, для внешних диверсий. Поиск ответа на этот вопрос является целью настоящей статьи.

Методы. Попытки изучения представлений о будущем в массовом сознании россиян неоднократно предпринимались представителями различных социально-гуманитарных наук. Среди исследований последних лет можно отметить философские [1], социологические $[4 ; 9 ; 11]$ и социально-психологические [13; $14 ; 22]$ интерпретации народного образа грядущего. Во многих из указанных работ приводятся результаты авторских эмпирических исследований, что придает данным публикациям особую ценность. Вместе с тем собственно политологическое осмысление темы происходило довольно редко. К числу немногочисленных исключений из правила можно отнести исследования образов будущего в конституционных проектах [12], в публичном общественно-политическом дискурсе [3], а также публикацию о проектировании будущего в программатике российских политических партий [21].

Несмотря на то что проблему нельзя назвать неизученной, пока еще нет специального научного исследования, в котором содержался бы анализ базовых ценностных ориентиров россиян и их представлений о справедливом общественном устройстве в их соотнесении с политическими проектами ведущих российских политических акторов и государственно-конституционными преобразованиями 2020 года. Осознание необходимости такого исследования предопределило выход данной статьи.

Для определения того, насколько инициированный политическими элитами концепт «социального государства» способен удовлетворить запрос массового сознания российских граждан на образ будущего страны, авторы использовали широкий набор как общенаучных, так и специально-политологических подходов и методов. Был осуществлен анализ первичных и вторичных результатов исследований общественного мнения. Статья строит- 
ся на интерпретации результатов социологических опросов, проведенных крупнейшими социологическими службами России: ВЦИОМ, Левада-Центр, ФОМ, а также на основе изучения программ политических партий, выступлений российских политических деятелей и наблюдений за российским политическим процессом.

Анализ. Можно выделить два уровня факторов, на практике существенно затрудняющих сведение ориентиров, важных для общества и элиты для их солидарного движения в политическое будущее, к какому-либо универсальному теоретическому понятию. Даже если это понятие (например, «социальное государство», «правовое государство», «гражданское общество» и т. д.) прочно укоренилось в современных политических дискурсах и не вызывает отторжения у участников политического процесса.

Один фактор - это давление на сознание участников современного политического процесса знания о прошлом государства и общества (особенно ближайшем), существенно возросшего в последние десятилетия благодаря развитию средств массовых коммуникаций. Другой фактор - текущее состояние российс- кой социально-политической системы, в контексте которого сознание граждан должно вести поиск связи своих представлений о будущем общества и государства со смыслом понятия «социальное» и «правовое» государство.

У разных поколений связь между отношением к прошлому, настоящему и будущему складывается специфически (табл. 1).

Наиболее привлекательными в качестве примеров для подражания в будущем большинству российских граждан кажутся дореволюционное время и брежневская эпоха. Это понятно. В нормальном обществе всегда доминирует запрос на социальную и политическую стабильность, спокойную, размеренную жизнь без социальных катаклизмов.

Вместе с тем переломные эпохи («лихие 1990-е», сталинский СССР и октябрь 1917 г.) поколение $\mathrm{Z}$ оценивает гораздо позитивнее, чем граждане старшего и среднего возрастов, бывшие реальными современниками этих исторических процессов. Для молодого поколения, чье сознание изначально нацелено на освоение больших объемов противоречивой информации, не существенны те моменты в политическом опыте советских государства и общества, которые старшему поколению ме-

Таблица 1. Значимые различия в отношении к прошлому, настоящему и будущему России у представителей четырех поколений россиян

Table 1. Significant differences in the attitude to the past, present and future of Russia among representatives of four generations of Russians

\begin{tabular}{|c|c|c|c|c|}
\hline \multirow[b]{2}{*}{$\begin{array}{c}\text { Характеристики отношения } \\
\text { к прошлому, настоящему и будущему России }\end{array}$} & \multicolumn{4}{|c|}{ Поколения россиян } \\
\hline & $\begin{array}{c}\text { BB } \\
(1944- \\
1968 \text { г. p. })\end{array}$ & $\begin{array}{c}X \\
(1969- \\
1984 \text { г. р. })\end{array}$ & $\begin{array}{c}Y \\
(1985- \\
1999 \text { г. р. })\end{array}$ & $\begin{array}{c}Z \\
(2000- \\
2003 \text { г. p. })\end{array}$ \\
\hline Позитивная оценка настоящего России ** & 4,01 & 4,48 & 4,43 & 3,91 \\
\hline Способность влиять на настоящее России ** & 3,39 & 4,14 & 4,54 & 4,39 \\
\hline Позитивная оценка будущего России ** & 4,59 & 5,05 & 4,67 & 4,53 \\
\hline Способность влиять на будущее России ** & 4,19 & 4,56 & 5,07 & 4,95 \\
\hline $\begin{array}{l}\text { Ценность коллективного прошлого как источника уроков } \\
\text { для будущего ** }\end{array}$ & 5,46 & 5,97 & 5,50 & 5,38 \\
\hline $\begin{array}{l}\text { Общая воспринимаемая преемственность коллективной ис- } \\
\text { тории ** }\end{array}$ & 4,89 & 4,78 & 4,58 & 4,40 \\
\hline Дореволюционное время как образец для будущего России * & 3,28 & 3,29 & 2,76 & 2,55 \\
\hline $\begin{array}{l}\text { Время после Февральской революции как образец для бу- } \\
\text { дущего России * }\end{array}$ & 1,54 & 1,84 & 2,13 & 2,05 \\
\hline $\begin{array}{l}\text { Время после Октябрьской революции как образец для бу- } \\
\text { дущего России * }\end{array}$ & 1,52 & 1,74 & 2,00 & 2,19 \\
\hline Сталинское время как образец для будущего России * & 1,75 & 2,26 & 2,31 & 2,27 \\
\hline Брежневское время как образец для будущего России * & 2,69 & 2,90 & 2,42 & 2,37 \\
\hline Время перестройки как образец для будущего России * & 1,84 & 1,60 & 2,01 & 2,15 \\
\hline Ельцинский период как образец для будущего России * & 1,59 & 1,55 & 1,83 & 2,39 \\
\hline
\end{tabular}

Примечание. Источник: [14, с. 83-84]. * - 5-балльная шкала; ** - 7-балльная шкала. 


\section{ПОЛИТИЧЕСКИЙ ПРОЦЕСС В СОВРЕМЕННОЙ РОССИИ}

шают быть единодушным в признании советской внутренней политики в XX столетии образцом для подражания в будущем. Тем, что можно сегодня и завтра на уровне Конституции связать с понятиями «правовое государство» и «социальное государство».

Сознание субъектов политики балансирует между потребностью в политическом выборе остаться в границах рационального и безопасного. То есть в границах политических идей и решений, найденных предками и проверенных их опытом. И в то же время пониманием, что изменения необходимы и сейчас, и, особенно, в будущем. Границы этого балансирования массового сознания существенно шире, чем те, которые ему способны задать понятия «социальное государство», или «правовое государство». Отечественные политологи, в 90-е гг. прошлого века оптимистично писавшие о перспективах либеральной модернизации России, о развитии начал гражданственности и самоуправления в общественной и государственной жизни, о вхождении России в «семью демократических народов», уже столкнулись однажды с проблемой невместимости реалий российской политики в понятийный аппарат либеральной теории. Они не могли себе представить, насколько спустя десятилетие политические предпочтения граждан и элит, мотивации их выбора в пользу образа будущего страны качнутся в сторону консерватизма и традиционализма, соответствующих ценностей и практик [2; 8; 20]. Если помнить реальный советский опыт, то границы этого баланса определяла масштабная и относительно стройная по смыслу система советской официальной идеологии, которая все естественные подвижки в массовом сознании в его отношении к будущему вводила в достаточно жесткое русло смыслов и политических дискурсов.

В чем, пожалуй, едины участники современного политического процесса в нашей стране (вне зависимости от их идеологических предпочтений), так это в использовании в своих представлениях на тему образа будущего крайне мифологизированных образов как досоветского, так и советского политического опыта. «Мифологизированных» не в смысле их недостоверности, а в плане высокой эмоциональности и устойчивой стереотипности формулировок и оценок, которые стоят за этими образами.

Необходимо отметить еще одно немаловажное обстоятельство. Позитивное отношение молодежи к советскому опыту свидетельствует не столько о ее консерватизме и усвоении от старших лишь «моделей пассивного выживания и адаптации» $[9$, с. 36], сколько о недовольстве настоящим. Советское прошлое противопоставляется молодыми современности. На основании качественного анализа интервью студентов московских вузов исследователи В.А. Касамара и А.А. Сорокина формулируют пять дихотомий, связанных с восприятием поколением $\mathrm{Z}$ Советского Союза и современной России (см. табл. 2).

Совершенно очевидно, что в сознании молодежи возникает не образ советского прошлого, которое хотели бы восстановить молодые люди (они не жили в СССР и мало о нем знают), а образ некоего идеального общества под условным брендом «Советский Союз». Об отсутствии ностальгии по СССР у молодых ясно свидетельствуют данные социологических исследований. Согласно опросу ВЦИОМ, среди респондентов, сожалеющих о распаде СССР, преобладают люди пенсионного возраста (85\%), доля молодых составляет лишь $27 \%$. Большая часть поколения Z о крушении Советского Союза не сожалеет $(39 \%)$ или не имеет ясного мнения на этот счет (34\%) [24].

Социологи отмечают еще одну «точку соприкосновения» поколений - скептическую оценку современности. По данным исследований, на протяжении довольно длительного времени россияне испытывают чувства неуверенности и тревоги. Согласно опросам ЛевадаЦентра, среди проблем, волнующих россиян на протяжении более двадцати лет, преобладают боязнь болезней, угроза мировой войны, страх перед произволом, беззаконием и бедностью [5]. Как видно из данного списка, неудовлетворенными у большинства россиян остаются материальные потребности.

Таким образом, сложившееся в массовом сознании представление о будущем является комбинацией отрицательных суждений о некоторых аспектах настоящего, которому противопоставляются фрагменты мифологизированного прошлого. 
Социальный запрос на будущее России в политических проектах и массовом сознании граждан

\section{Таблица 2. Основные дихотомии при сравнении СССР и современной России}

Table 2. Key dichotomies when comparing the USSR and contemporary Russia

\begin{tabular}{|l|l|}
\hline \multicolumn{1}{|c|}{ СССР } & \multicolumn{1}{|c|}{ Современная Россия } \\
\hline Дружелюбная атмосфера, взаимопомощь & $\begin{array}{l}\text { Недоверие друг к другу, чувство ненависти, } \\
\text { враждебность }\end{array}$ \\
\hline Идеология, объединяющая людей & Отсутствие национальной идеи \\
\hline Советские культурные достижения & Прозападная массовая культура \\
\hline Социальные гарантии & Социальная незащищенность \\
\hline Великая держава & Слабое коррупционное государство \\
\hline
\end{tabular}

Примечание. Источник: [11, с. 112].

Субъекты нынешней российской политики, оценивая реалии досоветского и советского времени, обмениваясь такими воспоминаниями (прежде всего в интернет-пространстве), маркируют, таким образом, «точку невозврата» в отечественном либерально-демократическом политическом процессе. Ту «точку», после прохождения которой социально-политической системе не дано вернуться в своем развитии назад. Большинство авторов разнообразных проектов будущего России сходятся в том, что будущее невозможно воспроизвести в каких-либо, прежде известных, национально-исторических форматах. Они признают, что логика современных глобализационных процессов во всем мире обусловливает необходимость двигаться только вперед. Это признают не только сторонники либерального развития России по «магистральной дороге цивилизации» в направлении «общечеловеческих ценностей», но и идеологи неокоммунистических проектов в духе Г.А. Зюганова [10], а также авторы неоконсервативных проектов в духе А.Г. Дугина [6] и А.А. Проханова.

Элита получила сегодня возможность, при отсутствии внятно сформулированной идеологии коммуникации ее с российским гражданским обществом, «оптимизировать» свою работу над системой мотивирования граждан к патриотическому мышлению и поведению.

За счет, прежде всего, выделения в советском политическом опыте тех знаковых событий и процессов, которые настраивают сознание граждан на оптимистический лад и вселяют в него уверенность, что Россию ждет великое будущее даже в том случае, если мы сегодня ничего точно об этом будущем сказать не можем. В настоящий момент в нашей стране осуществлена очень удобная для управления локализация научных и публичных дис- куссий на тему будущего страны. Суть ее в том, чтобы свести публичные дискуссии на тему советского прошлого и постсоветского будущего нашей страны до масштаба, не угрожающего стабильности демократических институтов в нашей стране в условиях политической и экономической модернизации, которая раз за разом начинается и, к сожалению, каждый раз заканчивается результатами, не удовлетворяющими ни общество, ни элиту.

Локализация социально значимых знаний и оценок вокруг отдельных исторических событий позволяет решить проблему, чрезвычайно важную для нынешней российской власти. Проблему поддержания ее легитимности в пространстве внутрироссийской политики в условиях, когда в мировой политике по разным причинам эта легитимность в последние годы понесла заметный ущерб. Центральное место в технологиях налаживания позитивных коммуникаций с гражданским обществом и стремлении повлиять таким образом на социальный запрос на будущее занимают оценки и образы Великой Отечественной войны, подвига в ней советских граждан. Так формируется доминантный патриотический дискурс коммуникаций общества и власти, а также внутрисоциальных коммуникаций.

Дискурс обеспечивает, как показало минувшее голосование по поправкам к Конституции РФ, взаимопонимание нынешней российской властной элиты с достаточно большим числом рядовых граждан. В то же время официальная актуализация патриотического дискурса таит в себе, в перспективе, и определенный риск для легитимности действующей власти. Источником угрозы, на наш взгляд, является то, что в массовом сознании граждан способность ныне действующих институтов Российского государства управлять 


\section{ПОЛИТИЧЕСКИЙ ПРОЦЕСС В СОВРЕМЕННОЙ РОССИИ}

политическим процессом, в том числе формировать социальный запрос на его будущее, напрямую и тесно увязывается с Великой Отечественной войной и Победой. В официальных и неофициальных дискурсах на эту тему массовому сознанию трудно найти ответ на ключевой для легитимности власти вопрос: к какому будущему состоянию политики, какими путями и с какими интересами нынешняя властная элита намерена вести гражданское общество в «светлое будущее».

В этих дискурсах, при всей их яркости и продуктивности для решения задачи патриотического воспитания, содержится в основном лишь доступная массовому сознанию российских граждан информация о том, от какого сложного, противоречивого и драматичного прошлого их намерена увести действующая элита. Критически неясен при этом ответ на ключевой вопрос: насколько будет соответствовать это будущее массовым ожиданиям безопасности, справедливости, этичности политики? Нынешние патриотические дискурсы коммуникации властной элиты и гражданского общества, дискурсы о Великой Отечественной войне и Великой Победе не содержат на этот счет какой-либо убедительной информации. По крайней мере, в том масштабе и того качества, которые позволили бы гражданскому обществу мифологически, на уровне устойчивых формул политической коммуникации, соединить свою патриотическую рефлексию на тему войны и Победы со своими ожиданиями «светлого будущего» для себя и своих потомков.

Акцент на историческом преемстве действующей власти не вредит ее легитимности до тех пор, покуда в силу не всегда предсказуемых внутриполитических и внешнеполитических обстоятельств гражданское общество прямо не ставит перед ней вопрос: что реально дает для настоящего и будущего страны систематическое совместное переживание элитой и обществом их трагического и героического прошлого? Почему консенсус власти и общества по этому поводу не способствует решению накопившихся текущих социальных проблем и каковы перспективы их решения в будущем?

Этот политический риск для устойчивого функционирования современного российс- кого государства вытекает из стремления массового сознания найти связь и провести сравнение между прошлым и настоящим страны (на уровне стереотипных мифологических представлений) для осмысления оценки перспектив ее политического и социально-экономического будущего.

Между тем социологические замеры показывают, что оценки текущего состояния российской социально-политической системы очень противоречивы.

Не очень значимой представляется населению нашей страны многопартийность. Так, $24 \%$ россиян считает, что стране достаточно одной партии, еще $6 \%$ сомневается, что партии нужны вообще [15, с. 109]. Уверенность же остальных граждан в важности многопартийности сочетается с довольно низкой положительной оценкой данного института в целом: среди авторитетных социальных структур политические партии занимают, как правило, последние места [17]. Причина столь скептического отношения общества кроется, видимо, в том, что за время своего существования партии не сумели выполнить своей социальной роли. «...Поставленные перед выбором оставаться выразителями интересов своих сторонников, составляющих часть общества... или использовать свой политический статус в качестве дивиденда, делегированного властью за "системность", современные политические партии России предпочли второй путь... - пишут В.Г. Егоров и А.А. Морозов, Встроенные во властную вертикаль парламентские партии утратили способность выражать интересы граждан... Вмешательство в решение конкретных проблем граждан, бизнеса не входит в планы партий, так как это может вызвать недовольство чиновников и возможное “повреждение" их статуса в системе» [7, с. 22].

Невысоко оценивают граждане и такую демократическую процедуру, как голосование. «Отношение населения к выборам выглядит неоднозначным, - пишут социологи ЛевадаЦентра Д. Волков и С. Гончаров. - С одной стороны, на протяжении многих лет наблюдается устойчивое предпочтение выборов другим способам назначения мэров и губернаторов... а также преобладающее негативное отношение к идее ограничения права участия в выборах. С другой стороны, качество выбо- 
ров оценивается населением довольно низко... При этом в числе приоритетов для подавляющего числа россиян честные выборы занимают одно из последних мест, различные социальные проблемы волнуют людей намного больше» [4, с. 12].

Равнодушие к классическим либеральным институтам и практикам не означает, однако, отрицание россиянами демократии: $62 \%$ респондентов признают ее необходимость для России. Различие заключается в моделях народовластия, на которые ориентируются граждане: лишь $13 \%$ респондентов хотели бы видеть демократию такой же, как в Европе и Америке; 16 \% считают идеалом советский вариант народовластия и подавляющее большинство (55 \%) мечтает о демократии «совершенно особой, соответствующей национальным традициям и специфике России» [4, с. 3-4]. Среди важнейших оснований такой особой демократии - соблюдение гражданами законов вне зависимости от их социального статуса (36 \%), забота власти о нуждах людей (34 \%) и свобода выражения мнения о государственных делах (31\%) [4, с. 5].

Исследования показывают, что в массовом сознании значительной части российских граждан в качестве справедливого доминирует образ будущего страны, основанный на «левых» ценностях. Возникает резонный вопрос: почему эти представления не находят отражение в соответствующем голосовании граждан за «левые» партийно-идеологические проекты на выборах различного уровня. Казалось бы, в программах КПРФ и «Справедливой России» (а также других партий «левой» ориентации) эти ценности обоснованы и изложены в развернутом виде и должны выступать действенным мотивирующим фактором для голосования за «справедливое» общественнополитическое и социально-экономическое устройство. Однако реальные результаты выборов в Государственную думу и президентских выборов последних двух десятилетий не подтверждают прямой зависимости между «левыми» настроениями электората и голосованием за соответствующие партии и представляющих их кандидатов.

Проще всего это можно было бы объяснить наличием мощного административного и информационного ресурсов у действующе- го Президента и «Единой России», которые позволяют эффективно влиять на избирателей в период предвыборных кампаний. Этот фактор действительно имеет место, но, на наш взгляд, не является определяющим. Важнейшее значение имеет использование ментальных особенностей политической культуры россиян, которое позволяло и в очередной раз (на референдуме по поправкам в Конституции РФ) позволило обосновать целесообразность поддержки действующего Президента.

В этой политической культуре, детерминированной драматической историей России, причудливо синтезировались и укрепились достаточно противоречивые ценности и установки. С одной стороны, сформировалось понимание необходимости сильного государства, способного защитить страну от внешней угрозы и обеспечить порядок в обществе. Это державное начало дополняется персонифицированным восприятием сущности государственной власти, обусловленным многовековой монархической и 70-летней советской традицией. Такое патерналистское восприятие государства, регулирующего и контролирующего все сферы общественной жизни, особенно укрепилось в советский период. Не случайно, что даже на пике либеральных настроений и надежд в политической жизни России в 1993 г. авторы Конституции РФ, наряду с закреплением основных прав и свобод граждан, включили в нее понятие социального государства.

Тем не менее либеральная мотивация возвращения России в семью «демократических цивилизованных народов» не сработала для значительной части населения. Прежде всего в силу недовольства граждан сформировавшимся в постсоветской России политическим и социально-экономическим строем (олигархический капитализм, коррупция, бюрократия, неправедный суд, социальный раскол и т. д.). Важную роль сыграло также отсутствие четкого и понятного большинству населения стратегического целеполагания проводимых демократических преобразований. Это существенно отличает ситуацию от периода СССР, когда важнейшую мотивационную роль для советских граждан играло идеологическое обоснование их значимости в качестве первопроходцев и строителей ком- 


\section{ПОЛИТИЧЕСКИЙ ПРОЦЕСС В СОВРЕМЕННОЙ РОССИИ}

мунизма - «светлого будущего для всего человечества».

Либеральная идея гражданских прав и свобод, воплощенная на практике в конкретных преобразованиях «лихих 1990-х» в период строительства «дикого капитализма», не просто не смогла заменить это мессианское начало в политической культуре россиян, но была нацелена на формирование определенной ущербности и негативное восприятие дореволюционного имперского прошлого и тем более тоталитарного советского наследия. «Светлое либеральное будущее», по мнению российских реформаторов, уже давно существует на Западе, и России нужно просто воплотить апробированные демократические институты и механизмы их функционирования. Однако их реальное формирование и функционирование с самого начала осуществлялось самими либералами с грубейшими нарушениями демократических принципов. Объяснялось это реформаторами угрозой возвращения коммунистов к власти и опасностью реанимации советской системы. Поэтому для сохранения власти Б.Н. Ельцина, как гаранта слома коммунистической модели и продолжателя либеральных преобразований, были использованы все средства - от мощнейшей кампании информационно-манипуляционного воздействия на избирателей до прямых фальсификаций результатов выборов. Это не могло не подорвать доверия граждан не только к переходному либеральному состоянию России, но и к перспективам этой модели образа «счастливого будущего». Такой заимствованный, «вторичный» образ будущего России, лишенный «высокого мессианского смысла», не смог стать действенным мотивационным фактором либеральных преобразований. Резкое падение жизненного уровня большинства населения в 1990-е гг. и формирование олигархической компрадорской модели капитализма не было воспринято российскими гражданами как необходимая и оправданная жертва на пути к «светлому либеральному будущему».

Социологические опросы, проведенные ФОМ в 2007 г. и 2011 г., показали, что на вопрос «Как вы считаете, современное российское общество в целом устроено справедливо или несправедливо?» только 12 \% опрошенных однозначно ответили положительно.
О том, что устройство несправедливо, в 2007 г. однозначно ответили 68 \%, а в 2011 г. - $61 \%$ респондентов. Более того, даже через два десятилетия после распада СССР, половина респондентов оценивала сложившееся общественное устройство в стране как менее справедливое, чем советское [19].

В условиях конституционно закрепленных перекосов в системе разделения властей в пользу Президента РФ важнейшие демократические институты, такие как парламентаризм, многопартийность, конкурентные выборы, оппозиция, оказались политически неэффективными. Одними из первых это ощутили на себе сами сторонники либерализма, которые достаточно быстро были вытеснены из большой политики на периферию общественно-политической жизни России. Однако партии других идеологических направлений также не стали авторитетными субъектами политики в представлении большинства российского населения. Обусловлено это тем, что принятие стратегически важных решений для страны зависит, прежде всего, от Президента Российской Федерации.

Во многом это объясняет тот факт, что те «левые» предпочтения в образе будущего России, которые социологи выявляют у значительной части населения, не становятся определяющим фактором в процессе голосования на парламентских выборах. Фракция КПРФ в Государственной думе на пике своего успеха в результате выборов 1995 г. ничего не смогла сделать, чтобы изменить либеральный курс политического и социально-экономического развития страны. Поражение Г.А. Зюганова на президентских выборах 1996 г. объясняется, по мнению многих исследователей, прямой фальсификацией результатов голосования. Однако на выборах 2000 г. он не смог составить конкуренцию более молодому и харизматичному В.В. Путину в значительной степени из-за отсутствия результатов парламентской деятельности КПРФ в Государственной думе.

Сформированный в информационном пространстве антиобраз лидера коммунистов, как «вечно второго», стал одним из факторов, ограничивающих расширение электоральной поддержки КПРФ. Кроме того, сказалось целенаправленное конструирование «Справедли- 
вой России» - еще одной «левой» партии социал-демократического толка, которая на выборах в Государственную думу стала получать от 7 до 13 \% голосов избирателей. Как видно, именно в ее программе представлен тот проект образа будущего России, который концентрированно включает в себя социальный запрос на исторически обусловленные специфические ценности политической культуры россиян и модернизированную модель социального государства. Однако создание этой партии не предполагало реальной конкуренции ее лидера В.В. Путину, так как изначально «Справедливая Россия» представляла себя как оппозицию негативным проявлениям и последствиям деятельности «Единой России» (коррупции, бюрократизму, социальной несправедливости и т. д.). На президентских выбоpax 2004 г. С.М. Миронов публично обосновал свою поддержку В.В. Путина как общенационального лидера. На выборах 2008 г. «Справедливая Россия» также поддержала выдвинутую В.В. Путиным кандидатуру Д.А. Медведева. Тем самым партия была дискредитирована как самостоятельная оппозиционная сила и утвердилась в массовом сознании как «левая» пропрезидентская партия. Соответственно не воспринимается как самодостаточная и политическая программа партии, хотя она и включает в себя реальный социальный запрос граждан на «левые» ценности.

С приходом к власти В.В. Путина его обоснование стратегии самостоятельного и самодостаточного развития России, подкрепленное попытками поставить под президентский контроль процессы политического и социальноэкономического развития страны, стало одним из факторов его высокого рейтинга в качестве общенационального лидера. В условиях благоприятной конъюнктуры на внешних рынках такая политика привела к тому, что увеличение государственных доходов от продажи нефти и газа позволило осуществить определенный подъем всех сфер экономики и уровня жизни населения, остановить опасные центробежные тенденции в регионах, восстановить обороннопромышленный комплекс и укрепить армию, возродить статус России в качестве великой державы на международной арене.

Поддержка этих позитивных процессов населением и укрепления механизмов силь- ного государства способствовала тому, что российские граждане достаточно легко согласились на пресловутую политическую «рокировку» В.В. Путина и Д.А. Медведева, которая позволила формально сохранить требования Конституции РФ о двух сроках президентства. Не вызвала массового негодования и политика по конструированию политических партий, поддерживающих Президента, хотя состав и деятельность самой «Единой России» с самого начала вызывала серьезные претензии у значительной части россиян. Всплеск оппозиционных выступлений в российских столицах 2011-2012 гг. опирался на узкую социальную базу и не охватил регионы. Кредит доверия В.В. Путину, обусловленный восстановлением России в качестве великой державы, достиг своего пика в период кризиса на Украине и возвращения Крыма в состав России. Однако последующее обострение международных отношений и политика санкций против России со стороны США и западноевропейских стран, наряду с падением цен на нефть и газ на мировых рынках, вновь актуализировали социальную проблематику в настроениях российских граждан.

Социологический опрос, проведенный ВЦИОМ в 2018 г., показал, что на вопрос «За последний год наше общество стало менее или более социально справедливым?» только 16 \% респондентов ответили, что оно стало скорее более социально справедливым. Более половины опрошенных не увидели позитивных отношений в данной области, а 28 \% респондентов были уверены, что ситуация изменилась в худшую сторону [18]. Отвечая на прямой вопрос «По Вашему мнению, политика российских властей сегодня способствует или препятствует укреплению социальной справедливости в нашем обществе?» только 29 \% респондентов ответили, что «скорее способствует», $32 \%$ - «скорее препятствует» и $30 \%$ выбрали ответ «никак не влияет на справедливость общества» [18].

По результатам опроса Левада-Центра в октябре 2019 г. только $3 \%$ респондентов однозначно положительно ответили на вопрос «Совпадают ли в России интересы власти и общества?»; еще $22 \%$ ответили «скорее да»; «скорее нет»- $42 \%$; «определенно нет»-30\%; затруднились ответить $-4 \%$ опрошенных [16]. 


\section{ПОЛИТИЧЕСКИЙ ПРОЦЕСС В СОВРЕМЕННОЙ РОССИИ}

Такие настроения стали одним из мотивов внесения поправок в Конституцию РФ в 2020 году. Несмотря на явную политическую задачу этих поправок («обнуление» сроков президентства В.В. Путина), очевидно и стремление расширить и укрепить социальный блок Конституции РФ. Это ответ на общественный запрос о необходимости ориентироваться на принципы социальной справедливости, как стратегического будущего развития России. Однако соотнесение принятых изменений с «левыми» представлениями о справедливом общественно-политическом устройстве свидетельствует о том, что поправки нацелены лишь на текущее повышение уровня легитимности власти Президента. Главная претензия населения к сформированной в 1990-е гг. компрадорской модели экономических отношений не нашла своего разрешения в конституционных поправках. Интересы крупных собственников, ориентированных на вывоз природных ресурсов России за рубеж, остались не затронутыми. Сохранившаяся либеральная модель экономики оставляет мало возможностей для расширения социальных функций государства, не позволяет устранить базовую несправедливость в распределении собственности и ее производных ресурсов. Соответственно сегодняшнее сильное государство и потенциал общественной стабильности не получают мотивационного подкрепления надеждами граждан на социально справедливое будущее России.

Периодические публичные акции использования государственного контроля за действиями собственников крупных кампаний и громкие разоблачения коррупционеров на различных уровнях власти лишь подтверждают незыблемость действия «закона олигархических тенденций» в современной России. Они не создают конституционно закрепленных основ для системного контроля за социальными приоритетами экономической деятельности и призваны, чаще всего, продемонстрировать функциональность и значимость «ручного управления» главы российского государства. Декларирование «Единой Россией» своего превращения в партию «народного большинства» на волне реализации социально ориентированных государственных программ воспринимается гражданами как стремление при- глушить назревающий протестный потенциал и завуалировать сращивание интересов власти и собственников.

Результаты. Как видится, формирование социально востребованного образа будущего России будет связано с обновлением лидерского состава отечественных «левых» политических партий и соответствующим их институциональным и идеологическим переформатированием. Сегодняшние программы КПРФ и «Справедливой России» (Коммунистическая партия Коммунисты России (КПКР), Коммунистическая партия социальной справедливости (КПСС) и другие небольшие «левые» партии не обладают ресурсами для превращения в реальную политическую силу в современной России), несмотря на наличие в них востребованных значительной частью населения социально-политических ценностей и приоритетов, не получают соответствующей поддержки на выборах. У каждой из данных партий своя собственная совокупность причин ограниченности электората, но общим является неспособность лидеров обосновать реальность своей победы, прежде всего, на президентских выборах. Г.А. Зюганов, несмотря на свой статус политического старожила и тяжеловеса, имеет уже закрепленный в массовом сознании образ лидера «партии прошлого», адаптированной в качестве подконтрольной системной оппозиции к политической жизни современной России. Не случайно, что лидер коммунистов не стал выдвигать свою кандидатуру на последних выборах Президента Российской Федерации. С.М. Миронов изначально не претендовал на реальную конкуренцию с В.В. Путиным, нивелировав тем самым в глазах населения политические запросы возглавляемой им партии. Соответственно отсутствие реальных претензий на государственное лидерство и возможность изменить стратегию развития государства и общества нивелирует в глазах населения и тот образ будущего, который представлен в программах данных «левых» партий.

Поэтому уже в ближайшем будущем объективно назрела потребность консолидации «левых» партий, или, по крайней мере, выдвижение ими новых политических лидеров, ориентированных на борьбу за российскую модель социал-демократического развития 
страны. Установление реального контроля со стороны государства и общества за природными ресурсами и их использованием, внедрение дифференцированной системы налогообложения, государственное стимулирование внутреннего производства - представляет собой единственно возможный для России способ формирования общественно-политического и социально-экономического строя, воспринимаемого большинством населения как социально справедливого, обеспечивающего достойное будущее для российских граждан.

Понятия «социальное государство» и «правовое государство», если подходить к ситуации формально, обладают тем уровнем смысловой широты, при котором способны охватить все разнообразие и все противоречия в запросах общества на приведение социально-политической системы России в состояние, при котором она будет способной прогрессировать в границах демократических ценностей и процедур. В то же время эти понятия не обладают способностью конкретизировать связь между запросами различных групп граждан на будущее страны и теми предложениями на этот счет, которые сегодня пытаются адресовать обществу партийные лидеры и теоретики.

С этим обстоятельством связан второй очевидный риск для будущей устойчивости отечественной социально-политической системы и для ее способности прогрессировать. Общество, получившее ответ о своем будущем, но ответ недостаточно конкретный, проявляет (чему много примеров показывает политическая жизнь постсоветских государств) повышенный интерес к политическим технологиям, обещающим решение насущных проблем «в обход» проблемы политического будущего, решение «здесь и сейчас». А таким свойством сегодня в наибольшей мере обладают, к сожалению, технологии «цветных революций». В современном мире множится число обществ, в которых применение этих политических технологий, обещающих решение проблем без оглядки на прошлое и без глубоких раздумий о будущем, замещающих в массовом сознании рациональную рефлексию на эту тему протестными эмоциями, уже фактически лишило позитивного политическо- го будущего. Понимание гражданами и элитой того, что простой актуализацией в публичных политических дискурсах тех, или иных общепринятых теоретически понятий и формул не решить проблему появления четких ориентиров для развития российской политики, могло бы быть определенной гарантией от такой пугающей перспективы.

\section{СПИСОК ЛИТЕРАТУРЫ}

1. Ананченко, А. Б. «Образы будущего» и национальная идея России / А. Б. Ананченко // Философия политики и права. -2019 . - № 10. - С. 256-265.

2. Белякова, А. М. Консерватизм как идеология современной России / А. М. Белякова // Актуальные проблемы гуманитарных и естественных наук. -2020 . - № 1. - С. 139-142.

3. Вилков, А. А. Образы будущего в политологическом и публичном дискурсах современной России / А. А. Вилков // Известия Саратовского университета. Новая серия. Серия: Социология. Политология. - 2020. - Т. 20, № 1. - С. 64-68. - DOI: https://doi.org/10.18500/1818-9601-2020-20-1-64-68.

4. Волков, Д. Демократия в России: установки населения. Сводный аналитический отчет / Д. Волков, С. Гончаров. - М. : Левада-Центр, 2015. $-43 \mathrm{c}$.

5. Динамика основных страхов // ЛевадаЦентр : [сайт]. - Электрон. текстовые дан. - Режим доступа: https://www.levada.ru/2020/04/09/dinamikaosnovnyh-strahov/ (дата обращения: 12.08.2020). Загл. с экрана.

6. Дугин, А. Г. Абсолютная родина. Пути Абсолюта. Метафизика Благой Вести. Мистерии Евразии / А. Г. Дугин. - М. : АРКТОГЕЯ-центр, 1999. $752 \mathrm{c}$.

7. Егоров, В. Г. Особенности современного российского партогенеза / В. Г. Егоров, А. А. Морозов // Власть. - 2012. - № 9. - С. 21-25.

8. Епремян, М. А. Консерватизм в политическом реформировании современной России: преимущества и недостатки / М. А. Епремян // Общество: политика, экономика, право. - 2018. № 12 (65). - С. 35-40.

9. Зоркая, Н. Ностальгия по прошлому, или Какие уроки могла усвоить и усвоила молодежь / Н. Зоркая // Вестник общественного мнения. 2007. - № 3. - C. 35-46.

10. Зюганов, Г. А. О русских и России / Г. А. Зюганов // Коммунистическая партия Российской Федерации : [сайт]. - Электрон. текстовые дан. - Режим доступа: https://kprf.ru/personal/zyuganov/zbooks/ 25058.html (дата обращения: 20.07.2020). - Загл. с экрана. 
11. Касамара, В. А. Образ СССР и современной России в представлениях студенческой молодежи / В. А. Касамара, А. А. Сорокина // Общественные науки и современность. -2014 . - № 1. C. $107-118$.

12. Кузнецов, И. И. Представления о будущем в проектах реформирования Конституции Российской Федерации / И. И. Кузнецов // Образы будущего России: желаемое-возможное - необходимое : материалы Всерос. науч.-практ. конф., г. Москва, 8-9 июня 2016 г. / под общ. ред. А. Б. Ананченко ; Моск. пед. гос. ун-т, Ин-т истории и политики. М. : Изд-во МПГУ, 2016. - С. 16-40.

13. Мехришвили, Л. Л. Влияние образа будущего на жизненный успех и стратегии его достижения современной российской молодежи / Л. Л. Мехришвили, В. В. Гаврилюк, Т. В. Гаврилюк // Россия реформирующаяся : ежегодник. Вып. 15 / отв. ред. М. К. Горшков. - М. : Новый Хронограф, 2017. C. 369-394.

14. Нестик, Т. А. Образ будущего России у представителей поколения Z / Т. А. Нестик, В. Н. Ролдугина // Человек и мир. - 2018. - Т. 2, № 2. - С. 75-87.

15. Общественное мнение - 2016 : ежегодник. М. : Левада-Центр, 2017. - 272 с.

16. Общество и государство // Левада-Центр. Аналитический центр Юрия Левады : [сайт]. - Электрон. текстовые дан. - Режим доступа: https:// www.levada.ru/2019/11/28/obshhestvo-i-gosudarstvo/ (дата обращения: 10.12. 2019). - Загл. с экрана.

17. Рейтинги партий, доверия политикам, одобрения работы государственных и общественных институтов // ВЦИОМ : [сайт]. - Электрон. текстовые дан. - Режим доступа: https://wciom.ru/index. php?id=236\&uid=3626 (дата обращения: 07.08.2020). Загл. с экрана.

18. Социальная справедливость в России // ВЦИОМ : [сайт]. - Электрон. текстовые дан. Режим доступа: https://wciom.ru/index.php?id=236 \&uid=9443 (дата обращения: 10.12. 2019). - Загл. с экрана.

19. Справедливость не торжествует // ФОМ : [сайт]. - Электрон. текстовые дан. - Режим доступа: https://fom.ru/Nastroeniya/10263 (дата обращения: 10.12. 2019). - Загл. с экрана.

20. Федулов, А. М. Возвращение к идеям консерватизма в современной России / А. М. Федулов // Наука и бизнес: пути развития. - 2013. - № 9 (27). C. 55-60.

21. Шаповалов, В. Л. «Образы будущего» в партийном пространстве России / В. Л. Шаповалов // Политика развития, государство и мировой порядок : материалы VIII Всерос. конгресса политологов / под общ. ред. О. В. Гаман-Голутвиной, Л. В. Сморгунова, Л. Н. Тимофеевой. - М. : АспектПресс, 2018. - С. 578-579.
22. Шестопал, Е. Б. Сравнительный анализ образов своей страны у жителей российских регионов / Е. Б. Шестопал, Н. В. Смулькина, И. В. Морозикова // Сравнительная политика. - 2019. - Т. 10, № 3. - C. 74-94. - DOI: https://doi.org/10.24411/22213279-2019-10031.

23. Шмелева, О. Ю. Социальные медиа как механизм формирования образа современного государства в политическом сознании россиян / О. Ю. Шмелева, Д. И. Каминченко // Вестник Московского государственного областного университета : электрон. журн. - 2019. - № 3. - С. 87-106. DOI: https://doi.org/10.18384/2224-0209-2019-3-969.

24. Back in the USSR? // ВЦИОМ : [сайт]. - Электрон. текстовые дан. - Режим доступа: https://wciom. ru/index.php?id=236\&uid=497 (дата обращения: 12.08.2020). - Загл. с экрана.

\section{REFERENCES}

1. Ananchenko A.B. «Obrazy budushchego» i nacional'naya ideya Rossii ["Images of the Future" and the National Idea of Russia]. Filosofiya politiki $i$ prava, 2019, no. 10, pp. 256-265.

2. Belyakova A.M. Konservatizm kak ideologiya sovremennoj Rossii [Conservatism as the Ideology of Modern Russia]. Aktual'nye problemy gumanitarnykh i estestvennykh nauk, 2020, no. 1, pp. 139-142.

3. Vilkov A.A. Obrazy budushchego v politologicheskom i publichnom diskursah sovremennoj Rossii [Images of the Future in the Political Science and Public Discourses of Modern Russia]. Izvestiya Saratovskogo universiteta. Novaya seriya. Seriya: Sotsiologiya. Politologiya, 2020, vol. 20, no. 1, pp. 64-68. DOI: https://doi.org/10.18500/1818-9601-2020-20-1-64-68.

4. Volkov D., Goncharov S. Demokratiya v Rossii: ustanovki naseleniya. Svodnyi analiticheskii otchet [Democracy in Russia: Attitudes of the Population. Consolidated Analytical Report]. Moscow, Levada-Tsentr [Levada-Center], 2015. 43 p.

5. Dinamika osnovnykh strakhov [Dynamics of Basic Fears]. Levada-Tsentr [Levada-Center]. URL: https://www.levada.ru/2020/04/09/dinamikaosnovnyh-strahov/ (accessed 12 August 2020).

6. Dugin A.G. Absolyutnaya rodina. Puti Absolyuta. Metafizika Blagoi Vesti. Misterii Evrazii [Absolute Homeland. Paths of the Absolute. Metaphysics of the Good News. Mysteries of Eurasia]. Moscow, ARKTOGEYA-tsentr Publ., 1999. 752 p.

7. Egorov V.G., Morozov A.A. Osobennosti sovremennogo rossijskogo partogeneza [Features of Modern Russian Partogenesis]. Vlast', 2012, no. 9, pp. 21-25.

8. Epremyan M.A. Konservatizm v politicheskom reformirovanii sovremennoj Rossii: preimushchestva 
i nedostatki [Conservatism in the Political Reform of Modern Russia: Advantages and Disadvantages]. Obshchestvo: politika, ekonomika, pravo [Society: Politics, Economics, Law], 2018, no. 12 (65), pp. 35-40.

9. Zorkaya N. Nostal'giya po proshlomu, ili Kakie uroki mogla usvoit' i usvoila molodezh' [Nostalgia for the Past, or What Lessons Could and Have Been Learned by the Youth]. Vestnik obshchestvennogo mneniya [The Russian Public Opinion Herald], 2007, no. 3, pp. 35-46.

10. Zyuganov G.A. O russkikh i Rossii [About Russians and Russia]. Kommunisticheskaya partiya Rossiiskoi Federatsii [Communist Party of the Russian Federation]. URL: https//kprf.ru/personal/zyuganov/ zbooks/25058.html (accessed 20 July 2020).

11. Kasamara V.A., Sorokina A.A. Obraz SSSR i sovremennoj Rossii v predstavleniyah studencheskoj molodezhi [The Image of the USSR and Modern Russia in the Representation of Student Youth]. Obshchestvennye nauki i sovremennost' [Social Sciences and Contemporary World], 2014, no. 1, pp. 107-118.

12. Kuznetsov I.I. Predstavleniya o budushchem v proektakh reformirovaniya Konstitutsii Rossiiskoi Federatsii [Ideas About the Future in the Projects of Reforming the Constitution of the Russian Federation]. Ananchenko A.B., ed. Obrazy budushchego Rossii: zhelaemoe - vozmozhnoe - neobkhodimoye [Images of the Future of Russia: The Desired is the Possible]. Moscow, Izd-vo MPGU, 2016, pp. 16-40.

13. Mekhrishvili L.L., Gavrilyuk V.V., GavrilyukT.V. Vliyanie obraza budushchego na zhiznennyj uspekh i strategii ego dostizheniya sovremennoj rossijskoj molodezhi [The Impact on the Vision of the Future to Life Success and Strategies to Achieve it by Modern Russian Youth]. Gorshkov M.K., ed. Rossiya reformiruyushchayasya. Moscow, Novyy Khronograf Publ., 2017, no. 15, pp. 369-394.

14. Nestik T.A., Roldugina V.N. Obraz budushchego Rossii u predstavitelej pokoleniya Z [Image Of Russia's FutureAmong Representatives of Russian Generation Z]. Chelovek i mir, 2018, vol. 2, no. 2, pp. 75-87.

15. Obshchestvennoe mnenie - 2016: yezhegodnik [Public Opinion - 2016: Yearbook]. Moscow, Levada-Tsentr, 2017. 272 p.

16. Obshchestvo i gosudarstvo [Society and State]. Levada-Tsentr [Levada-Center]. URL: www.levada.ru/2019/11/28/obshhestvo-i-gosudarstvo/ (accessed 10 December 2019).
17. Reitingi partii, doveriya politikam, odobreniya raboty gosudarstvennykh i obshchestvennykh institutov [Party Ratings, Confidence in Politicians, Approval of the Work of State and Public Institutions]. VCIOM [Russian Public Opinion Research Center]. URL: https://wciom.ru/index.php?id=236\&uid=3626 (accessed 7 August 2020).

18. Sotsial'naya spravedlivost' v Rossii [Social Justice in Russia]. VCIOM [Russian Public Opinion Research Center]. URL: https://wciom.ru/index. php?id=236\&uid=9443 (accessed 10 December 2019).

19. Spravedlivost' ne torzhestvuet [Justice Does Not Prevail]. FOM. URL: https://fom.ru/Nastroeniya/ 10263 (accessed 10 December 2019).

20. Fedulov A.M. Vozvrashchenie k ideyam konservatizma v sovremennoj Rossii [Return to the Ideas of Conservatism in Modern Russia]. Nauka $i$ biznes: puti razvitiya [Science and Business: Development Ways], 2013, no. 9 (27), pp. 55-60.

21. Shapovalov V.L. «Obrazy budushchego» v partiinom prostranstve Rossii ["Images of the Future" in the Party Space of Russia]. Gaman-Golutvina O.V., Smorgunov L.V., Timofeeva L.N., eds. Politika razvitiya, gosudarstvo i mirovoi poryadok: materialy VIII Vseros. kongressa politologov [Development Policy, State and World Order. Materials of the $8^{\text {th }}$ AllRussian Congress of Political Scientists]. Moscow, Aspekt-Press Publ., 2018, pp. 578-579.

22. Shestopal E.B., Smulkina N.V., Morozikova I.V. Sravnitel'nyj analiz obrazov svoej strany u zhitelej rossijskih regionov [Comparative Analysis of the Images of Their Country Among Residents of Russian Regions]. Sravnitel'naya politika [Comparative Politics Russia], 2019, vol. 10, no. 3, pp. 74-94. DOI: https://doi.org/10.24411/2221-3279-2019-10031.

23. Shmeleva O.Yu., Kaminchenko D.I. Social'nye media kak mekhanizm formirovaniya obraza sovremennogo gosudarstva $v$ politicheskom soznanii rossiyan [Social Media as a Mechanism for the Formation of the Image of a Modern State in the Political Consciousness of Russians]. Vestnik Moskovskogo gosudarstvennogo oblastnogo universiteta [Bulletin of the Moscow State Region University], 2019, no. 3, pp. 87-106. DOI: https:// doi.org/10.18384/2224-0209-2019-3-969.

24. Back in the USSR? VCIOM. URL: https:// wciom.ru/index.php?id=236\&uid=497 (accessed 12 August 2020). 


\section{ПОЛИТИЧЕСКИЙ ПРОЦЕСС В СОВРЕМЕННОЙ РОССИИ}

\section{Information About the Authors}

Aleksander A. Vilkov, Doctor of Sciences (Politics), Professor, Head of the Political Science Department, Saratov State University named after N.G. Chernyshevsky, Astrakhanskaya St, 83, 410012 Saratov, Russian Federation, vil57@yandex.ru, https://orcid.org/0000-0003-4277-0372

Nikolaj I. Shestov, Doctor of Sciences (Politics), Professor, Political Science Department, Saratov State University named after N.G. Chernyshevsky, Astrakhanskaya St, 83, 410012 Saratov, Russian Federation, nikshestov@mail.ru, https://orcid.org/0000-0003-2220-7582

Andrei V. Abramov, Candidate of Sciences (Politics), Associate Professor, Department of Comparative Politics, Lomonosov Moscow State University, Leninskiye Gory, 1, 119991 Moscow, Russian Federation, abram-off@mail.ru, https://orcid.org/0000-0001-6528-4444

\section{Информация об авторах}

Александр Алексеевич Вилков, доктор политических наук, профессор, заведующий кафедрой политических наук, Саратовский национальный исследовательский государственный университет им. Н.Г. Чернышевского, ул. Астраханская, 83, 410012 г. Саратов, Российская Федерация, vil57@yandex.ru, https://orcid.org/0000-0003-4277-0372

Николай Игоревич Шестов, доктор политических наук, профессор кафедры политических наук, Саратовский национальный исследовательский государственный университет им. Н.Г. Чернышевского, ул. Астраханская, 83, 410012 г. Саратов, Российская Федерация, nikshestov@mail.ru, https://orcid.org/0000-0003-2220-7582

Андрей Вячеславович Абрамов, кандидат политических наук, доцент кафедры сравнительной политологии, Московский государственный университет им. М.В. Ломоносова, Ленинские горы, 1 , 119991 г. Москва, Российская Федерация, abram-off@mail.ru, https://orcid.org/0000-0001-6528-4444 